\title{
Performance of Asparagus sprengeri and Dracaena sanderiana in Different Potting and Rooting Media ${ }^{1}$
}

\author{
Saulo J. Rodriguez, Carlos Rivera-López, and Alejandro Santiago ${ }^{2}$
}

\section{INTRODUCTION}

The agricultural value of ornamental plant production in Puerto Rico for 1969-70 was estimated to have been about $\$ 3$ million. The exportation of foliage plants that year was considered the most important single item.

Dracaena sanderiana and Asparagus sprengeri, both members of the Lily family, are good representatives of foliage plant specialties. The first named, according to the information obtained from trade sources, is the foliage plant mostly sought for exportation. It is used widely in dish gardens for interior decoration. The second named is used in hanging baskets and for other outdoor arrangements.

Peat moss, mostly imported from Germany, is used for the propagation and exportation of all ornamental foliage plants. It has increased steadily in cost, mainly because of increased freight charges. A rough value of its importation into Puerto Rico was estimated recently at about $\$ 100,000$.

The Agricultural Experiment Station recently authorized a project to find a suitable local substitute for peat moss in growth mixtures. The substitute material should be 1 , available in ample quantities, 2, relatively inert and 3, light in weight. If possible, it also should be an industry by-product for mechanical handling. Several such materials were tested for growth and rooting media purposes. The results of these tests are reported here.

\section{MATERIALS AND METHODS}

\section{POTTING MEDIA FOR A. sprengeri}

Eight materials produced locally in relatively large quantities, with peat moss as a control, were mixed by hand in various proportions with perlite, calcined clay, vermiculite, and sand for drainage purposes. These various mixtures were then tested as potting media. The local materials were residues from the tobacco industry, wood shavings, sawdust, spent coffee grounds, coffee parchment, dry coffee leaves, sugarcane bagasse,

1 Manuscript submitted to the Editorial Board February 7, 1973.

2 Horticulturist, Agronomist, and Assistant Agronomist, respectively, Agricultural Experiment Station, University of Puerto Rico, Mayagüez Campus, Río Piedras, P.R. 
and muck soil. ${ }^{3}$ Each mixture contained 90 percent by volume of one of the above-mentioned materials and 10 percent of perlite, calcined clay, vermiculite or sand. This resulted in 36 different mixes.

$A$. sprengeri seedlings were transferred to 6 -inch white plastic pots each filled with one of the different potting mixtures. The pots were placed on a work bench in a glasshouse in which the temperature was partially controlled by air extractors and a water cooling system. A 50-percent shade-plastic saran cloth was placed over the plants to reduce light intensity.

Irrigation was provided regularly through capillary dripping tubes attached to a $3 / 4$-inch, plastic, water tube running along the center of the

TABLE 1.-Comparison of different polting media in the presence of perlile, calcined clay, vermiculile, and sand on the visual appearance of Asparagus sprengeri

\begin{tabular}{|c|c|c|c|c|}
\hline \multirow{2}{*}{ Material } & \multicolumn{4}{|c|}{ Visual rating of different potting mixtures ${ }^{1}$ mixed with- } \\
\hline & Perlite & Calcined clay & Vermiculite & Sand \\
\hline Tobacco stems & $0.98 \mathrm{efg}^{2}$ & $1.08 \mathrm{efg}$ & $0.56 \mathrm{~g}$ & 0.92 efg \\
\hline Wood shavings & 1.67 defg & 1.64 defg & $1.52 \mathrm{defg}$ & $1.07 \mathrm{efg}$ \\
\hline Sawdust & 1.49 defg & 1.53 defg & $1.68 \mathrm{defg}$ & $1.03 \mathrm{efg}$ \\
\hline Spent coffee & $1.02 \mathrm{efg}$ & $.78 \mathrm{fg}$ & $.65 \mathrm{~g}$ & $1.27 \mathrm{efg}$ \\
\hline Coffee parchment & 1.63 defg & $1.44 \mathrm{efg}$ & $.99 \mathrm{efg}$ & $1.28 \mathrm{efg}$ \\
\hline Dry coffee leaves & 2.33 bede & $3.17 \mathrm{ab}$ & 2.73 abed & 2.13 bcde \\
\hline Sugarcane bagasse & 1.79 cdefg & $1.43 \mathrm{efg}$ & 2.09 bedef & $1.30 \mathrm{efg}$ \\
\hline Muck soil & 2.95 abc & 2.18 bcde & $3.75 \mathrm{a}$ & $3.07 \mathrm{ab}$ \\
\hline Peat moss & $2.98 \mathrm{abc}$ & 2.34 bcde & $3.32 \mathrm{ab}$ & $3.16 \mathrm{ab}$ \\
\hline
\end{tabular}

1 Mean of four pots.

2 Mean with the same letter or set of letters do not differ significantly at the 5-percent level.

work bench. A 30-20-20 soluble fertilizer mixture was applied weekly at a rate supplying approximately 100 p.p.m. of nitrogen.

The pot treatments were distributed in a $6 \mathrm{X} 6$ triple-lattice design with six replications. After 65 days in the glasshouse, the plants were evaluated visually by four persons in terms of a 0 - to 5-rating scale (table 1). A 5point rating was given to an excellently healthy growing plant; a dead plant received a 0 rating. Intermediate values were based on that rating.

\section{ROOTING MEDIA FOR $D$. sanderiana}

Fifteen healthy, uniform $D$. sanderiana tops were individually wrapped in aluminum foil and each one planted in 16 different rooting media having

\& The muck soil was obtained from the Caño Martin Peña; it is mostly of mangrove origin. 
TABLE 2.-Rooting of foiled D. sanderiana tops in different media under mist propagation

\begin{tabular}{|c|c|c|c|c|}
\hline \multirow{2}{*}{ Rooting media } & \multicolumn{3}{|c|}{ Rooting percentage after- } & \multirow{2}{*}{$\begin{array}{c}\text { General appearance of cutting } \\
\text { and roots at the end of the } \\
\text { experiment }\end{array}$} \\
\hline & 18 days ${ }^{2}$ & 34 days & 61 days & \\
\hline Sawdust & 93.2 & 100.0 & 100.0 & $\begin{array}{l}\text { Chlorotic leaves, well de- } \\
\text { veloped roots }\end{array}$ \\
\hline Wood shavings & 0 & 0 & 20.0 & Chlorotic leaves \\
\hline Muck & 6.6 & 93.3 & 100.0 & $\begin{array}{l}\text { Green appearance, short } \\
\text { roots }\end{array}$ \\
\hline Muck + perlite $(1: 1)$ & 6.6 & 100.0 & 100.0 & $\begin{array}{l}\text { Green appearance, profuse } \\
\text { roots }\end{array}$ \\
\hline$\underset{(1: 1)}{\operatorname{Muck}}+$ vermiculite & $\mathbf{0}$ & 86.6 & 100.0 & Green appearance \\
\hline Dry coffee leaves & 93.3 & 100.0 & 100.0 & $\begin{array}{l}\text { Green leaves, well devel- } \\
\text { oped roots }\end{array}$ \\
\hline Peat moss. & 73.3 & 100.0 & 100.0 & $\begin{array}{l}\text { Green leaves, well devel- } \\
\text { oped roots }\end{array}$ \\
\hline Perlite & 66.6 & 100.0 & 100.0 & $\begin{array}{l}\text { Chlorotic appearance, } \\
\text { healthy well developed } \\
\text { roots }\end{array}$ \\
\hline Vermiculite & 66.6 & 100.0 & 100.0 & $\begin{array}{l}\text { Chlorotic appearance, long, } \\
\text { thick roots }\end{array}$ \\
\hline Water hyacinth roots & 93.3 & 100.0 & 100.0 & $\begin{array}{l}\text { Green color, well developed } \\
\text { roots }\end{array}$ \\
\hline Coffee parchment & 93.3 & 100.0 & 100.0 & $\begin{array}{l}\text { Chlorotic leaves, well de- } \\
\text { veloped roots }\end{array}$ \\
\hline Sugarcane bagasse & 80.0 & 100.0 & 100.0 & $\begin{array}{l}\text { Yellow green color, well } \\
\text { developed roots }\end{array}$ \\
\hline Spent coffee & 26.6 & 100.0 & 100.0 & Numerous short roots \\
\hline $\begin{array}{l}\text { Spent coffee + perlite } \\
(1: 1)\end{array}$ & 6.6 & 100.0 & 100.0 & $\begin{array}{l}\text { Roots better developed than } \\
\text { in spent coffee alone }\end{array}$ \\
\hline $\begin{array}{l}\text { Spent coffee + vermicu- } \\
\text { lite }(1: 1)\end{array}$ & 53.3 & 100.0 & 100.0 & $\begin{array}{l}\text { Roots better than spent } \\
\text { coffee alone }\end{array}$ \\
\hline Tobacco industry residue & 0 & 86.6 & 100.0 & $\begin{array}{l}\text { Rotten basal end, roots de- } \\
\text { veloped in the nodes }\end{array}$ \\
\hline
\end{tabular}

1 As root primordia visible to the naked eye.

components as shown in table 2 . The 16 treatments were placed in a constant mist propagator. Samples of five cuttings each were removed at 18, 34 and 61 days to observe their rooting behavior.

In a separate trial, 13 different rooting media having components as shown in table 3 were placed in 1-inch individual plastic pots. A 6-inch top of $D$. sanderiana was planted in each pot. The pots were placed in a constant mist propagator. At 18, 34, and 61 days, the plants from three of the pots of each media were pulled up and inspected to observe rooting and pot-bound formation of the media. 


\section{RESULTS AND DISCUSSION}

\section{PERFORMANCE OF $A$. sprengeri IN DIFFERENT POTTING MEDIA}

The results are presented in table 1 . Some native potting material can be substituted for peat moss in asparagus culture. Mixtures containing muck soil, sugarcane bagasse, or dry coffee leaves produced plants as healthy as those propagated in peat moss. The addition of perlite, calcined clay, or vermiculite to any of the different materials was no improvement over sand (table 1). Vermiculite added to muck soil produced better plants than calcined clay added to muck soil.

TABLE 3.-Rooting of D. sanderiana tops under mist propagation and stability of the media of the pulled out pot-bound plants

\begin{tabular}{lcrrll}
\hline \multirow{2}{*}{ Media } & \multicolumn{3}{c}{ Percentage rooting at- } & \multirow{2}{*}{$\begin{array}{c}\text { Stability of media after } \\
\text { 61 days }\end{array}$} \\
\cline { 2 - 4 } & $\mathbf{1 8}$ days & $\mathbf{3 4}$ days & $\mathbf{6 1 \text { days }}$ & \\
\hline Sawdust & 33.3 & 100.0 & 100.0 & Very stable \\
Wood shavings & 0 & 33.3 & 66.6 & Unstable, break easily \\
Muck soil & 0 & 100.0 & 100.0 & Stable \\
Dry coffee leaves & 66.6 & 100.0 & 100.0 & Very stable \\
Peat moss & 33.3 & 100.0 & 100.0 & Very stable \\
Perlite & 33.3 & 100.0 & 100.0 & Unstable, break easily \\
Vermiculite & 0 & 100.0 & 100.0 & Unstable, break easily \\
Water hyacinth roots & 66.6 & 100.0 & 100.0 & Very stable \\
Coffee parchment & 66.6 & 100.0 & 100.0 & Very stable \\
Spent coffee & 0 & 100.0 & 100.0 & Unstable \\
Tobacco industry residue & 0 & 100.0 & 100.0 & Unstable \\
Sugarcane bagasse & 0 & 100.0 & 100.0 & Very stable \\
Sand + peat moss & 0 & 66.6 & 100.0 & Unstable \\
\hline
\end{tabular}

A. sprengeri plants growing in peat moss or muck soil mixed with perlite excelled those growing in tobacco-industry residues, wood shavings, sawdust, spent coffee, or coffee parchment mixed with the same material. No difference was visible in the case of dry coffee leaves and sugarcane bagasse. The other materials mixed with perlite did not differ among themselves (table 1).

Well-decomposed dry. coffee leaves mixed with calcined clay permitted better plant growth than tobacco-industry residues, wood shavings, sawdust, spent coffee, coffee parchment, or sugarcane bagasse when mixed with the same material (table 1). Plants growing in muck soil or peat moss mixed with calcined clay rated better, however, than those growing in a mixture of spent coffee and calcined clay (table 1). No differences were noted between other mixtures containing calcined clay.

Results with mixtures containing vermiculite are presented in table 1. 
They reflect superiority of peat moss or muck soil mixtures over those containing tobacco-industry residues, wood shavings, sawdust, spent coffee, or coffee parchment for growing of $A$. sprengeri. The mixture of muck soil and vermiculite was superior even to sugarcane bagasse, but not to dry coffee leaves. The peat moss-vermiculite mixture was no better than those containing sugarcane bagasse or dry coffee leaves. The sugarcane bagassevermiculite mixture produced better plants than spent coffee-vermiculite or tobacco residue-vermiculite mixtures.

Mixtures containing sand again proved the superiority of muck soil and peat moss (table 1). Both proved superior to the others except the one containing dry coffee leaves and sand. No other differences were noted in the group.

In general, mixtures containing spent coffee or tobacco residues were unsuited for potting mixtures (table 1). Both materials held great promise because of their availability and possible mechanical handling. Spent coffee is a waste product from instant coffee processing plants. Two such plants are established in Puerto Rico and the disposal of the solid waste product is an added expense. Tobacco residues are found in relatively large quantities in tobacco processing plants. It is easily handled, but the material decomposes quite rapidly due possibly to its high mineral content. Spent coffee tends to cake because of its fine-texture particles. Further research may overcome that condition and improve its drainage capacity.

Several materials have been found, however, that can serve as good substitutes for peat moss, at least in Asparagus-potting mixtures. Muck soil, dry coffee leaves, and sugarcane bagasse produced healthy plants comparable to those grown in peat moss. Further trials with other ornamental plants, as well as determination of cost of handling, must be ascertained before final evaluation can be made.

\section{ROOTING MEDIA FOR D. sanderiana}

The results of rooting foiled and pot-bound $D$. sanderiana cuttings are presented in tables 2 and 3 . All the materials except wood shavings permitted rooting of $D$. sanderiana, both foiled or pot-bound. Dry coffee leaves, water hyacinth roots and coffee parchment induced rooting more quickly than the other materials. Tobacco residues caused a basal-end rot of the tops but the roots eventually developed at the nodes. The rooted tops developed a chlorotic appearance in some of the materials due possibly to impaired nutrition, nutrient leaching, and inertness of the material.

Tops placed in materials for pot-bound purposes rooted in all except wood shavings (table 3). The stability of the media differed greatly. Dry coffee leaves, sawdust, water hyacinth roots, well-decomposed sugarcane 
bagasse, and coffee parchment formed very stable pot-bindings comparable to those in peat moss.

The ornamental plant industry in Puerto Rico should utilize substitute native materials for peat moss. Several have been found for use in mixtures for rooting media. The cost of handling these has not been determined.

\section{SUMMARY}

A search has been conducted for suitable native materials for potting and rooting mixtures as substitutes for peat moss in the production of ornamental plants in Puerto Rico. Materials such as sawdust, wood shavings, muck soil, residues from the tobacco industry, spent coffee, coffee parchment, dry coffee leaves, sugarcane bagasse, and peat moss were mixed with perlite, vermiculite, calcined clay, or sand and these various mixtures were evaluated as rooting media. Asparagus sprengeri did not grow well in tobacco residue or spent coffee mixtures. Potting mixtures made with dry coffee leaves and muck soil were as good as those made with peat moss. Sugarcane bagasse, wood shavings, and sawdust were intermediate in value as potting mixtures for plant healthiness and appearance.

Dracaena sanderiana tops were placed in a constant mist propagator to root in different media. Wood shavings did not prove suitable for foiled or bound plants. Sugarcane bagasse, dry coffee leaves, coffee parchment, water hyacinth roots, and sawdust resulted in very stable bound plants comparable to those rooted in peat moss. Residues from the tobacco industry caused a basal-end rot but the cuttings eventually produced roots at the nodes.

\section{RESUMEN}

La Estación Experimental Agrícola comenzó a trabajar recientemente en un proyecto, en busca de materiales que puedan mezclarse y usarse como substitutos del musgo de pantano para sembrar plantas ornamentales en tiestos. Se mezclaron materiales tales como aserrín, viruta, suelo orgánico, palotes de tabaco, borras de café, pergamino de café, hojarasca de café, bagazo de caña y musgo de pantano con perlita, vermiculita, arcilla calcinada o arena. Las plantas de $A$ sparagus sprengeri no crecieron saludables en los residuos de tabaco (palotes) ni en las borras de café. Las que se sembraron en turba cenagosa y hojarasca de café se desarrollaron tan saludables como las sembradas en musgo de pantano. El bagazo de caña, el aserrín y la viruta revelaron tener un valor intermedio a juzgar por la apariencia de las plantas.

$A$ fin de que arraigaran se sembraron esquejes de $D$. sanderiana en distintos materiales y se colocaron en un propagador bajo una lluvia fina y constante. La viruta dio los peores resultados como medio para inducir el arraigo de plantas, tanto envueltas en papel de aluminio como sembradas en tiestos para restringir las raíces. La hojarasca de café, el bagazo de caña, el pergamino de café y las raíces del jacinto de agua hicieron que los esquejes desarrollaran un sistema de raices restringidas, tan estable como cuando se usa el musgo de pantano. Los esquejes sembrados en palotes de tabaco se pudieron en el extremo inferior, aunque produjeron raices en los nudos. 